\title{
Geochemistry of Chromitites in Eastern Part of Neyriz Ophiolite Complex (Southern Iran)
}

\author{
Pedram Attarzadeh1, Mehrdad Karimi2 ${ }^{*}$, Mohammad Yazdi ${ }^{3}$, Kamal Nouri Khankahdani2 \\ ${ }^{1}$ Department of Geology, North Tehran Branch, Islamic Azad University, Tehran, Iran \\ ${ }^{2}$ Department of Geology, Shiraz Branch, Islamic Azad University, Shiraz, Iran \\ ${ }^{3}$ Department of Geology, Faculty of Earth Sciences, Shahid Beheshti University, Tehran, Iran \\ Email: *karimimehrdad63@yahoo.com
}

How to cite this paper: Attarzadeh, P., Karimi, M., Yazdi, M. and Khankahdani, K.N. (2017) Geochemistry of Chromitites in Eastern Part of Neyriz Ophiolite Complex (Southern Iran).Open Journal of Geology, 7, 213-233.

https://doi.org/10.4236/ojg.2017.73015

Received: November 29, 2016

Accepted: March 11, 2017

Published: March 14, 2017

Copyright $\odot 2017$ by authors and Scientific Research Publishing Inc. This work is licensed under the Creative Commons Attribution International License (CC BY 4.0).

http://creativecommons.org/licenses/by/4.0/

\section{Open Access}

\begin{abstract}
The Neyriz ophiolite complex is a part of NW-SE thrust belt (Late Cretaceous) of Iran, which is over the Arabian plate margin. The complex is mainly composed of the upper mantle rocks. Our research was focused on the eastern part of Neyriz ophiolite complex so called as "Dowlat Abad-Tang e Hana". Mantle sequence of this ophiolitic complex is comprising predominantly of harzburgite and minor lherzolite, dunitc sheaths and chromite pods. Harzburgite is the most abundant ultramafic rock and is associated with the less dunite masses. The chromites are known with Cr\# 42 to 76 and Mg\# 73 to 89 . There is a negative correlation between $\mathrm{Cr} \#-\mathrm{Mg} \#$ which is one of the features of podiform chromites. The geochemistry of these chromites is consistent with the overall composition of podiform chromites in terms of $\mathrm{Cr} \#, \mathrm{Mg} \#$, the amounts of $\mathrm{Cr}_{2} \mathrm{O}_{3}\left(13.35 \%\right.$ - 54.47\%), $\mathrm{Al}_{2} \mathrm{O}_{3}(0.43 \%$ - 8\%), $\mathrm{MgO}(13.25 \%$ $38.56 \%), \mathrm{TiO}_{2}(0.003 \%-0.206 \%)$ as well as the correlations between various oxides and all of them are high chromium types.
\end{abstract}

\section{Keywords}

Ophiolite, Podiform Chromite, Neyriz, Iran

\section{Introduction}

Many researches show that ophiolite complexes are formed in different geotectonic positions [1] [2]. The Tethyan ophiolites in the Alpine-Himalayan orogenic system are exposed along curvilinear suture zones, bounding a series of continental fragments of Gondwana [3]. The Jurassic ophiolites in the Alpine-Apennine mountain belt in the west (Figure 1) commonly display MORB geochemistry [4] [5], while that Late Jurassic-Cretaceous ophiolites in the Taurid-Pontide (Turkey), Zagros (Iran), and the Himalayan mountain belts to the east show 


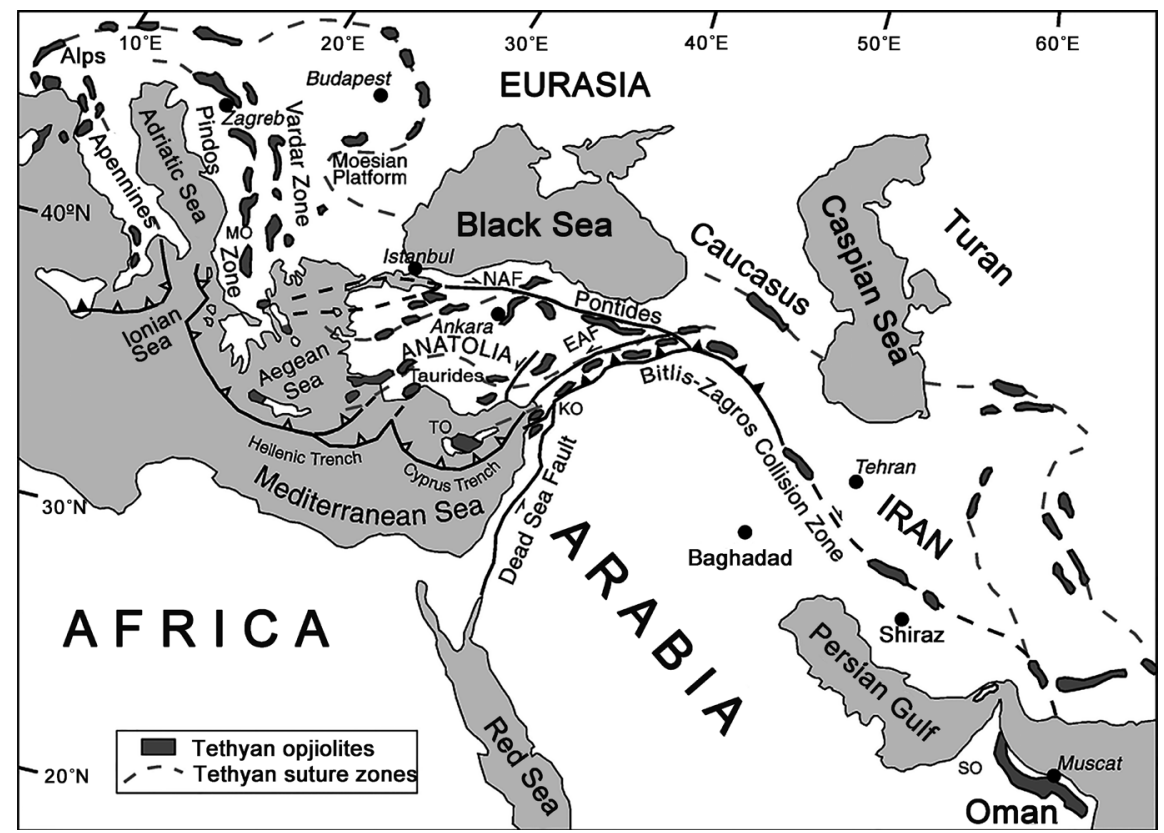

Figure 1. Distribution of Tethyanophiolitic rocks in Alpine-Himalayan orogenic belt [34].

geochemical affinities characteristic of supra subduction zone (SSZ) environments [6]-[15]. The ophiolitic complexes along Bitlis-Zagros Suture Zone include: Baer-Bassit (Syria), Hataya, Kizildag, and Cilo (Turkey); Kermanshah, Neyriz and Esfandagheh (Iran) [16] [17] [18]. Neyriz ophiolite is located in western part of Zagros thrust zone which separates Sanandaj-Sirjan crystalline complexes and Zagros thrust belt [19]. The Zagros fold-and-thrust belt extends in a NW-SE direction from the Iranian-Turkish border to Gulf of Oman (Figure 1) [20] [21]. This still-active belt results from the collision of the Arabian and Eurasian plates during Cenozoic and is one of the youngest continental collision belts within the Alpine-Himalayan orogenic system [22] [23]. The geodynamic evolution of the Zagros Belt is mainly related to the opening and closure of the Neo-Tethys Oceanic basin. A Late Permian rift episode led to the opening of the Neo-Tethyan Ocean between the Arabian and Iranian plates. The NE-dipping subduction of this oceanic branch beneath the Iranian continental margin [24] started in the Late Jurassic [25]. Chromites origin and their formation tectonic environment is a considerable discussion in geology [26]. Chromite, $\left(\mathrm{Mg}, \mathrm{Fe}^{2+}\right)$ $\left(\mathrm{Cr}, \mathrm{Al}, \mathrm{Fe}^{3+}\right)_{2} \mathrm{O}_{4}$, is a member of the spinel mineral series and it is usually found in mafic and ultramafic rocks as a rare mineral (approximately one percent) [27]. Chromite accumulates in mafic and ultramafic rocks in two forms: 1) As layers with different thickness and extent in mafic and ultramafic rocks in the continental crust, e.g. Bushveld complex in South Africa [28] and Stillwater complex in America [29]; 2) As podiform chromites in mafic and ultramafic rocks of ophiolite sequences. Chemical composition of chromite shows composition of the primary magma [30] [31]. In terms of chemical properties, chromite minerals existed in ophiolite series are divided into two groups: chromites with 
high $\mathrm{Cr}$ number $\left(\mathrm{Cr} \#=100^{*} \mathrm{Cr} / \mathrm{Cr}+\mathrm{Al}\right)(\mathrm{Cr} \#>70)$; and chromite with low $\mathrm{Cr}$ number $(\mathrm{Cr} \#<70)$. It is believed that the first group of chromites are formed in supra subduction zone as a result of boninite magma ascent and the second group are produced from a tholeiitic magma in an arc tectonic setting of an arc magma [32] [33]. The present paper is aimed to study mineralogy, geochemistry of chromites formed in the Eastern part of Neyriz ophiolite (Dowlat Abad-Tang e Hana).

\section{Geological Setting}

Iranian ophiolites are part of the eastern Tethys, that are important due to the unique geographic location joining the middle east and other Asia ophiolites (e.g. Pakistan and Tibet) to the Mediterranean and Carpathian ophiolites (e.g. Troodos, Greek and Eastern European) [11] [35]. The Neyriz ophiolite, found in a semi-arid environment along the Zargos thrust Zone, SW Iran, is a well-preserved part of the Tethyan oceanic lithosphere [36]. Neyriz ophiolite is located in western part of Zagros thrust zone which separates Sanandaj-Sirjan crystalline complexes and Zagros thrust belt. These ophiolites are remnants of the young Tethys oceanic crust and start from Tarus in Turkey and continue to Oman [37] [38]. According to spectrometry from biotite-bearing layers in garnet of amphibolite, related to mafic and ultramafic rocks of Neyriz ophiolite, primitive age of ophiolite replacement is middle Jurassic (170 Ma) and metamorphic stage was in last Cretaceous [39]. However, Neyriz ophiolite massifs were emplaced in Late Cretaceous because these ophiolites are covered by the Late Cretaceous Tarbur formation by discontinuities [40]. The Dowlat Abad-Tang e Hana is mainly formed of tectonized harzburgite, dunite with podiform chromitite, pyroxenite and crustal sequence e.g. basalt, gabbro and pelagic marine sediments with chert and radiolarite [41] [42] [43] [44] [45]. Magnetite veins and veinlets are also found in dunite and harzburgite (Figure 2).

\section{Materials and Methods}

Whole major oxides and elements of host rock and chromite ore were determined by a wavelength dispersive, Philips PW1480 4 PW X-ray fluorescence spectrometer (XRF) at the geochemistry laboratory of Kansaran-E Binalud Company (Tehran) utilizing by a side-window rhodium target X-ray tube. All analyses were made against standard calibration curves which were prepared using a set of USGS reference standards. Analyses of the major elements were conducted on fused glass disks. The disks are prepared using nine parts lithium borate flux and one part rock powder. The melted samples were poured into a preheated platinum mold and then chilled in order to form into a thick glass disk. The results obtained from chemical analysis of the samples are given in Table 1.

\subsection{Petrography}

The most extensive masses of ophiolite rocks in Dowlat Abad-Tang e Hana in- 


\section{Geological map of the Neyriz area}

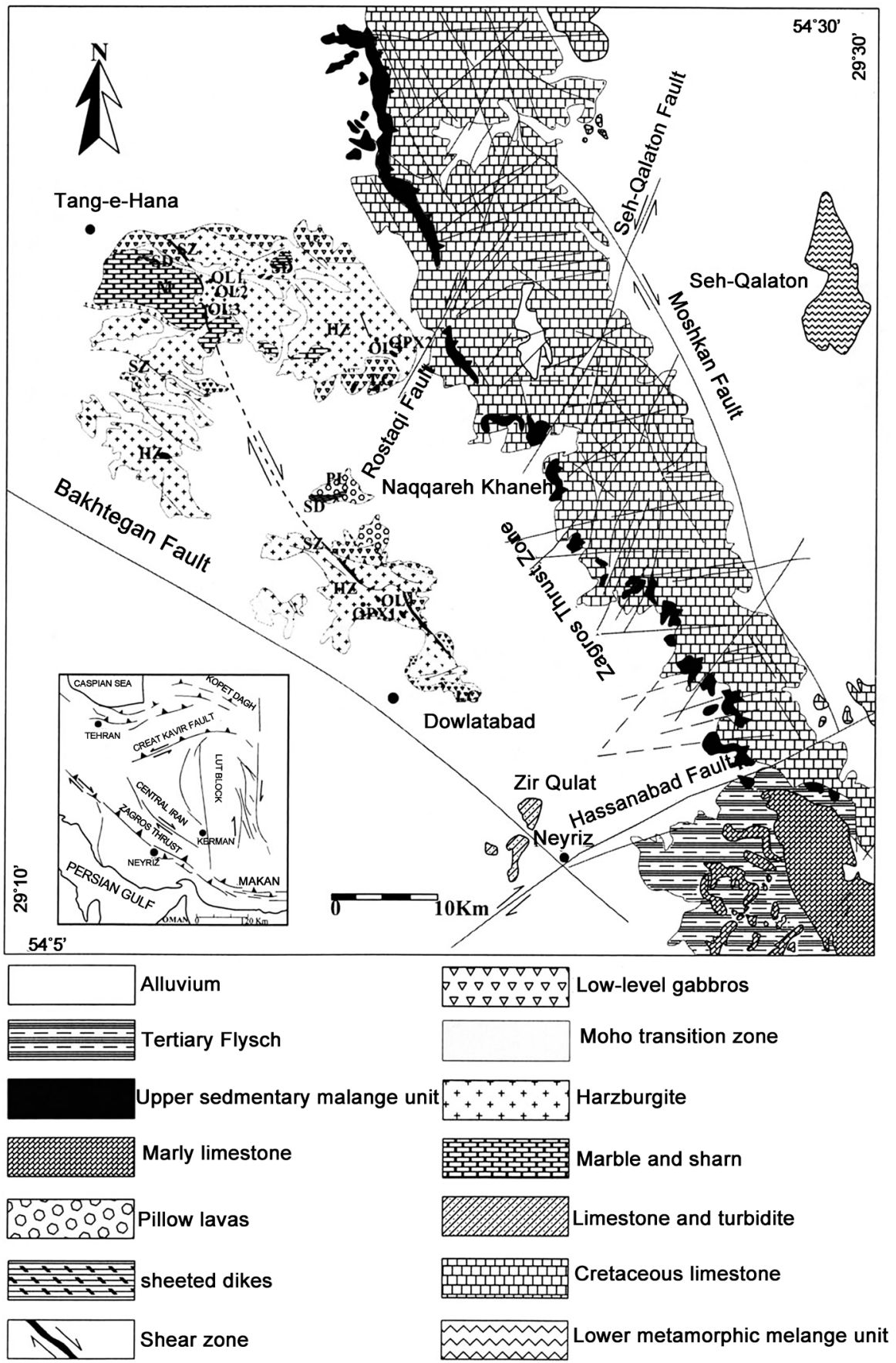

Figure 2. Geological map of Dowlat Abad-Tang e Hana area [36].

clude that mantel sequence containing: harzburgite, dunite, pyroxenite with chromitite, and crustal sequence including basalt, minor gabbro and pelagic sediments [46] [47]. In almost cases serpentinization has been developed along fractures of the rocks. Given that serpentinization is abundant in ultrabasic ophiolite rocks [48] [49], serpentinite alteration of peridotite rocks has occurred in varying degrees (10\% - 90\% serpentine) in the area [50]. Dunite is the most serpentinized rocks between the mantle peridotites. Harzburgite and serpentini- 
Table 1. The results of chemical analysis of chromite ore Dowlat Abad-Tang e Hana area.

\begin{tabular}{|c|c|c|c|c|c|c|c|c|c|c|c|c|}
\hline Element & $\mathrm{SiO}_{2}$ & $\mathrm{Al}_{2} \mathrm{O}_{3}$ & $\mathrm{CaO}$ & $\mathrm{Fe}_{2} \mathrm{O}_{3}$ & $\mathrm{FeO}$ & $\mathrm{K}_{2} \mathrm{O}$ & $\mathrm{MgO}$ & $\mathrm{MnO}$ & $\mathrm{Na}_{2} \mathrm{O}$ & $\mathrm{P}_{2} \mathrm{O}_{5}$ & $\mathrm{TiO}_{2}$ & $\mathrm{Cr}_{2} \mathrm{O}_{3}$ \\
\hline Unit & Wt\% & Wt\% & $\mathrm{Wt} \%$ & Wt\% & Wt\% & $\mathrm{Wt} \%$ & $\mathrm{Wt} \%$ & Wt\% & $\mathrm{Wt} \%$ & $\mathrm{Wt} \%$ & $\mathrm{Wt} \%$ & $\mathrm{Wt} \%$ \\
\hline D.T.1 & 1.5 & 5.4 & 0.05 & 3.48 & 17.67 & 0.02 & 14.56 & 0.307 & 0.02 & 0.02 & 0.086 & 54.34 \\
\hline D.T.2 & 2.87 & 4.47 & 0.05 & 3.3 & 16.77 & 0.03 & 13.82 & 0.305 & 0.02 & 0.02 & 0.087 & 54.47 \\
\hline D.T.3 & 2.94 & 5.57 & 0.1 & 3.74 & 18.9 & 0.02 & 13.25 & 0.303 & 0.03 & 0.02 & 0.197 & 51.87 \\
\hline D.T.4 & 25.07 & 0.58 & 0.04 & 2.01 & 10.21 & 0.01 & 32.11 & 0.194 & 0.02 & 0.02 & 0.04 & 16.5 \\
\hline D.T.5 & 5.8 & 3.3 & 0.05 & 3.33 & 16.87 & 0.02 & 16.53 & 0.322 & 0.01 & 0.001 & 0.094 & 46.88 \\
\hline D.T.6 & 10.11 & 2.64 & 0.13 & 2.95 & 14.95 & 0.01 & 20.44 & 0.289 & 0.01 & 0.02 & 0.094 & 41.62 \\
\hline D.T.7 & 9.55 & 6.38 & 0.36 & 3.27 & 16.56 & 0.02 & 17.18 & 0.278 & 0.02 & 0.02 & 0.147 & 41.72 \\
\hline D.T.8 & 5.86 & 3.77 & 0.05 & 3.71 & 18.8 & 0.02 & 15.16 & 0.374 & 0.02 & 0.001 & 0.122 & 47.49 \\
\hline D.T.9 & 38.53 & 0.43 & 0.56 & 1.41 & 7.17 & 0.02 & 38.56 & 0.169 & 0.02 & 0.02 & 0.003 & 41 \\
\hline D.T.10 & 26.32 & 0.75 & 0.16 & 1.69 & 8.6 & 0.01 & 35.46 & 0.159 & 0.03 & 0.003 & 0.033 & 13.35 \\
\hline D.T.11 & 14.26 & 5.95 & 4.71 & 3.67 & 18.5 & 0.01 & 14.56 & 0.308 & 0.01 & 0.02 & 0.206 & 35.07 \\
\hline D.T.12 & 19.45 & 1.24 & 0.18 & 2.19 & 11.12 & 0.02 & 30.02 & 0.228 & 0.03 & 0.002 & 0.074 & 25.98 \\
\hline D.T.13 & 6.52 & 3.4 & 0 & 3.5 & 17.75 & 0.02 & 17.17 & 0.333 & 0.03 & 0.02 & 0.094 & 46.79 \\
\hline D.T.14 & 6.4 & 8 & 0.22 & 3.69 & 18.75 & 0.01 & 15.22 & 0.312 & 0.03 & 0.02 & 0.059 & 42.31 \\
\hline D.T.15 & 9.5 & 3.63 & 0.33 & 3.34 & 16.94 & 0.01 & 19.14 & 0.343 & 0.02 & 0.01 & 0.084 & 41.75 \\
\hline D.T.16 & 12.16 & 3.3 & 0.05 & 3.51 & 17.78 & 0.02 & 20.22 & 0.309 & 0.02 & 0.02 & 0.151 & 37.39 \\
\hline Average & 23.15 & 3.69 & 0.44 & 3.049 & 15.45 & 0.016 & 20.83 & 0.28 & 0.021 & 0.014 & 0.098 & 39.90 \\
\hline
\end{tabular}

zed harzburgite are the most abundant ultramafic rocks in this area [50] [51]. Harzburgite, including olivine and orthopyroxene (Figure 3(a)). Dunites include olivine, pyroxene and chromite spinel (Figures 3(b)-(d)) which have been severely broken and crushed as a result of tectonic stress and tensile fractures caused by serpentinization process [46]. Due to alteration, dunites and pyroxenites have been severely serpentinized, called "serpentinit", since their most abundant and detectable mineral is serpentine (Figure 3(e)). Lherzolites of the area mainly consist of olivine, clinopyroxene and chrome spinel, which is considered as a minor mineral. Due to the less amount of olivine, these samples often show less serpentinization than harzburgites. Crystals of olivine and clinopyroxene are located within porphyroclasts orthopyroxene in the form of entries (Figure 3(f)). Pyroxenite is made up of pyroxene and a little plagioclase (Figure $3(\mathrm{~g})$ ). Gabbro is also made up of a set of orthopyroxene, clinopyroxene, plagioclase and olivine (Figure $3(\mathrm{~h})$ ). The main minerals of chromitites are chromite and olivine (serpentine), which generally have leopard skin texture.

\subsection{Geochemistry}

The weight percent of $\mathrm{Cr}_{2} \mathrm{O}_{3}$ content in Chromites of east Neyriz area is 13.35 54.47. Drastic changes in $\mathrm{Cr}_{2} \mathrm{O}_{3}$ content in one of the features of podiform chromites [52]. The amount of $\mathrm{Al}_{2} \mathrm{O}_{3}$ of these chromites varies in weight percent from $0.43-8$ and these values reflect the depletion $\mathrm{Al}_{2} \mathrm{O}_{3}$ in the chromitites of 

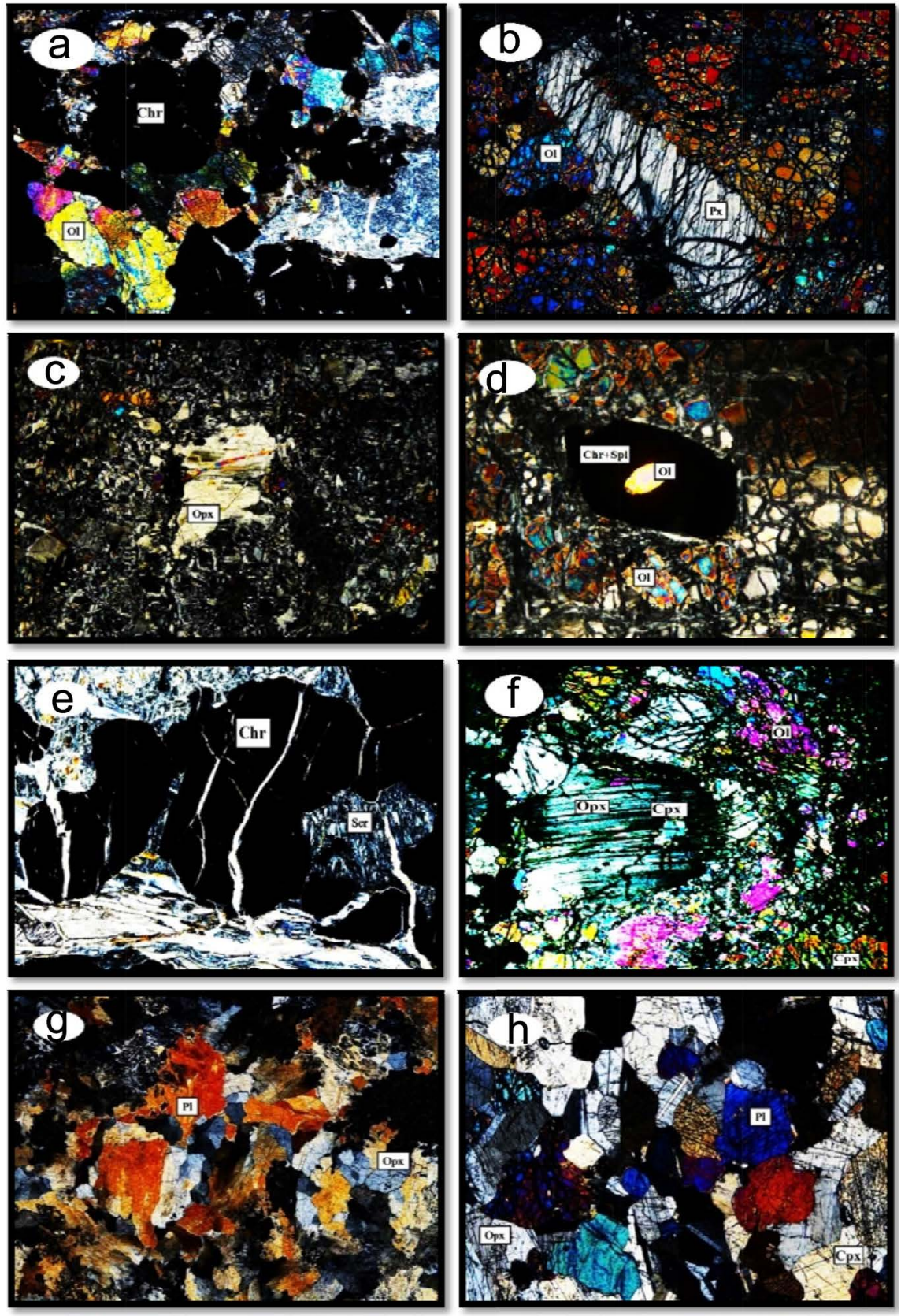

Figure 3. (a) Harzburgite with chromite; (b) Dunite containing olivine and pyroxene; (c) Serpentinizeddunite containing orthopyroxene; (d) Dunite containing olivine and chromite spinel; (e) Chromite with serpentine; (f) Clinopyroxene crystals in lherzolite having king band; (g) Norite with Orthopyroxene and plagioclase minerals; (h) Plagioclase, orthopyroxene and clinopyroxene in gabbro.

this area. The weight percent of $\mathrm{MgO}$ in chromites of this area is in the range of 13.25 - 38.56. With regard to the content of $\mathrm{Cr}_{2} \mathrm{O}_{3}$ and $\mathrm{Al}_{2} \mathrm{O}_{3}$ in podiform chromitite compounds, they are divided into two types, namely High- $\mathrm{Cr}\left(\mathrm{Cr}_{2} \mathrm{O}_{3}=\right.$ $45 \%-60 \%)$ and High- $\mathrm{Al}\left(\mathrm{Al}_{2} \mathrm{O}_{3}>25 \%\right)$. According to Table 2, chromitites of Dowlat Abad-Tang e Hana area are known with Cr\# of 42 to 76 and Mg\# of 73 to 89. Considering the $\mathrm{Cr}_{2} \mathrm{O}_{3}$ content of chromites of Dowlat Abad-Tang e area 
Table 2. Cr\# and Mg\# in the chromite ore of Dowlat Abad-Tang e Hana area.

\begin{tabular}{ccccccc}
\hline Element & $\mathrm{Al}$ & $\mathrm{Cr}$ & $\mathrm{Fe}$ & $\mathrm{Mg}$ & $\mathrm{Cr} \#$ & $\mathrm{Mg} \#$ \\
\hline D.T.1 & 0.18 & 0.313 & 0.533 & 1.49 & 63 & 74 \\
D.T.2 & 0.187 & 0.188 & 0.841 & 2.55 & 50 & 76 \\
D.T.3 & 0.271 & 0.891 & 1.01 & 3.07 & 76 & 76 \\
D.T.4 & 0.152 & 0.180 & 0.985 & 6.83 & 54 & 88 \\
D.T.5 & 0.132 & 0.169 & 1.21 & 6.19 & 56 & 84 \\
D.T.6 & 0.116 & 0.179 & 0.927 & 4.44 & 60 & 82 \\
D.T.7 & 0.176 & 0.169 & 1.12 & 7.91 & 49 & 88 \\
D.T.8 & 0.187 & 0.168 & 1.04 & 6.11 & 47 & 86 \\
D.T.9 & 0.0138 & 0.0106 & 4.76 & 30 & 43 & 87 \\
D.T.10 & 0.0668 & 0.190 & 1.04 & 7.72 & 73 & 89 \\
D.T.11 & 0.873 & 0.815 & 1.33 & 5.09 & 48 & 80 \\
D.T.12 & 0.0515 & 0.111 & 1.79 & 13.7 & 68 & 89 \\
D.T.13 & 0.304 & 0.264 & 1.22 & 4.7 & 46 & 80 \\
D.T.14 & 0.490 & 0.924 & 1.32 & 3.48 & 65 & 73 \\
D.T.15 & 0.313 & 0.231 & 1.25 & 5.99 & 42 & 83 \\
D.T.16 & 0.175 & 0.230 & 1.25 & 5.27 & 56 & 81 \\
Average & 0.230 & 0.314 & 1.351 & 7.28 & 56 & 82.25 \\
\hline
\end{tabular}

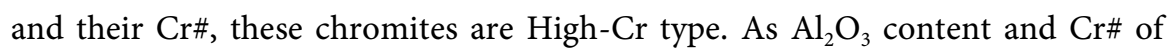
podiform chromitites are main indicators of High-Cr types from High-Al types, the use of $\mathrm{Al}_{2} \mathrm{O}_{3}$ diagram against $\mathrm{Cr} \#$ can be useful in distinguishing these two chromitites. The status of chromites is shown in Figure 4, this diagram represents a very weak positive correlation (0.041) between these two indices. Chromitites under study are High-Cr types.

High average of $\mathrm{MgO}(20.83 \mathrm{Wt} \%)$ represents the chromitite crystallization of the magmas of the area under study with high degree of partial melting which is related to deep peridotites [53]. This high average of $\mathrm{MgO}$ shows the Alpine type of the chromites of Dowlat Abad-Tang e Hana area because in a variety of stratiforms this average is less than $10 \mathrm{Wt} \%$ while this average is more in different types of stratiforms [54]. Moreover, the negative correlation of $\mathrm{Cr}_{2} \mathrm{O}_{3}-\mathrm{MgO}$ in chromitites of this area confirms that the chromitites are alpine type (Figure 5).

A negative correlation exists between $\mathrm{Cr} \#$ and $\mathrm{Mg} \#$ in chromitites of Dowlat Abad-Tang e Hana area (Figure 6), which reflects the probability of dissimilar associative coefficients for magnesium and iron between chromite and olivine in crystallization process [55]. In other words, along with the crystallization process advancement of chromite from magma, preferably iron enters chromite phase and magnesium tends to enter the composition of olivine. The relationship between $\mathrm{Cr} \#$ and $\mathrm{Mg} \#$ is the common feature of ophiolite type chromites [52].

The amount of $\mathrm{TiO}_{2}$ in chromitites of (Dowlat Abad-Tang e Hana) area is low (average is $0.098 \mathrm{Wt} \%$ ). The low amount of $\mathrm{TiO}_{2}$ is one of the distinguishing features of podirom chromitities from stratiforms. In other words, the amount 
of $\mathrm{TiO}_{2}$ in podiform chromitites in other parts of the world is less than $0.3 \%$ [52] [56]. The samples of area in the segregated diagram of $\mathrm{TiO}_{2}$ against $\mathrm{Cr}_{2} \mathrm{O}_{3}$ are in the range of podiform chromitites (Figure 7).

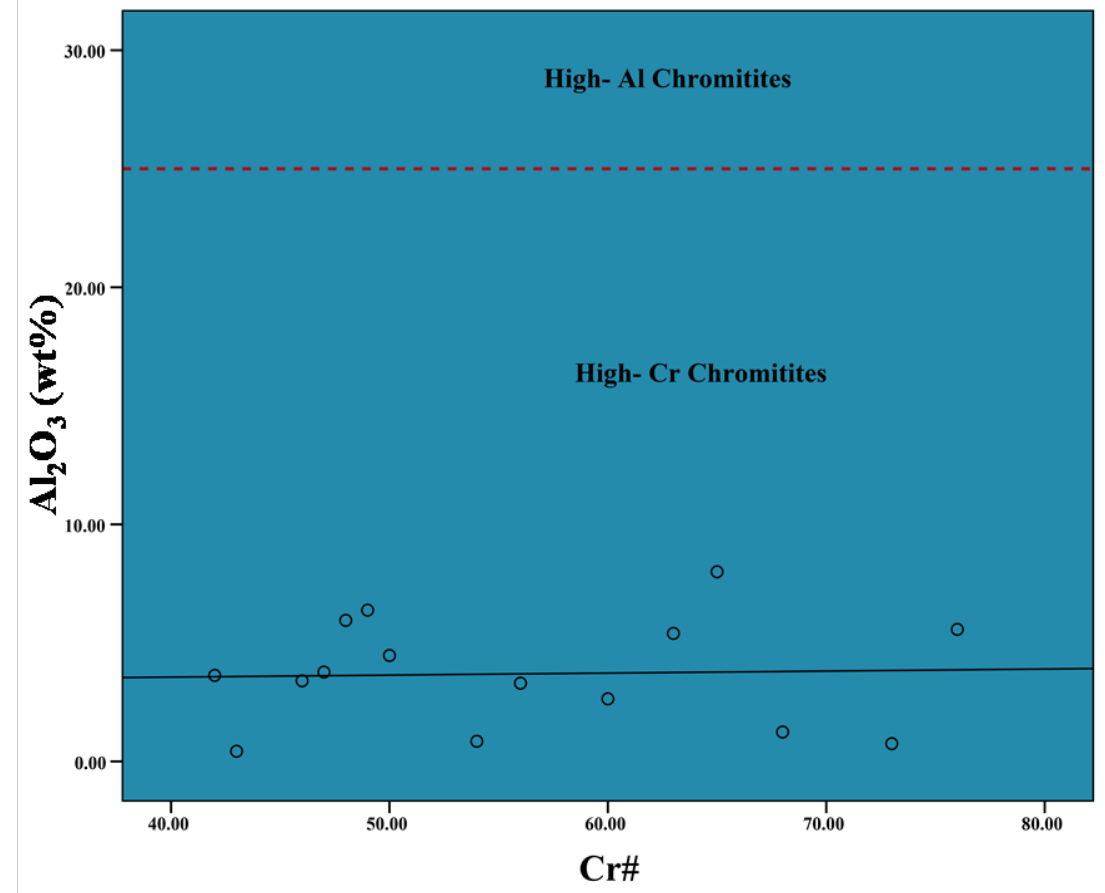

Figure 4. The status of chromitites of Dowlat Abad-Tang e Hana area in $\mathrm{Cr}^{-}-\mathrm{Al}_{2} \mathrm{O}_{3}$ diagram.

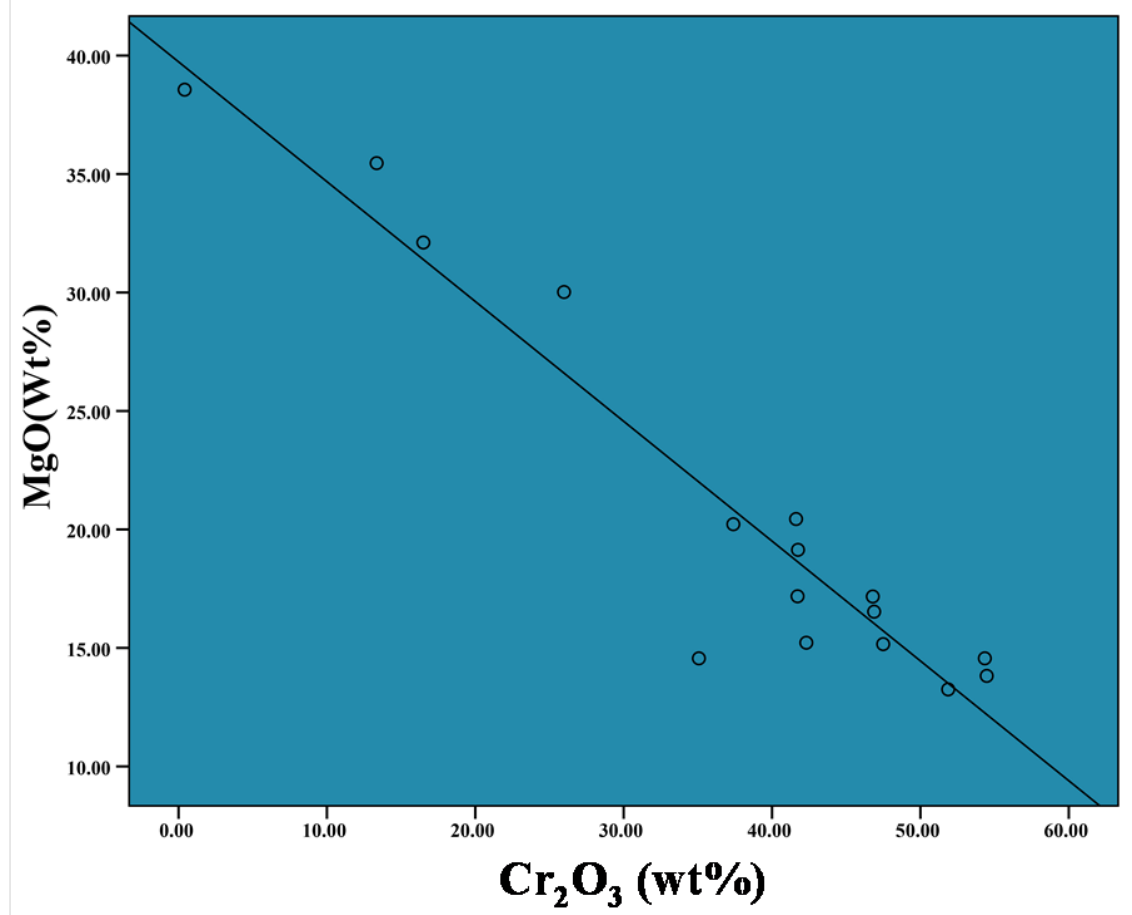

Figure 5. $\mathrm{Cr}_{2} \mathrm{O}_{3}-\mathrm{MgO}$ distribution diagram. 


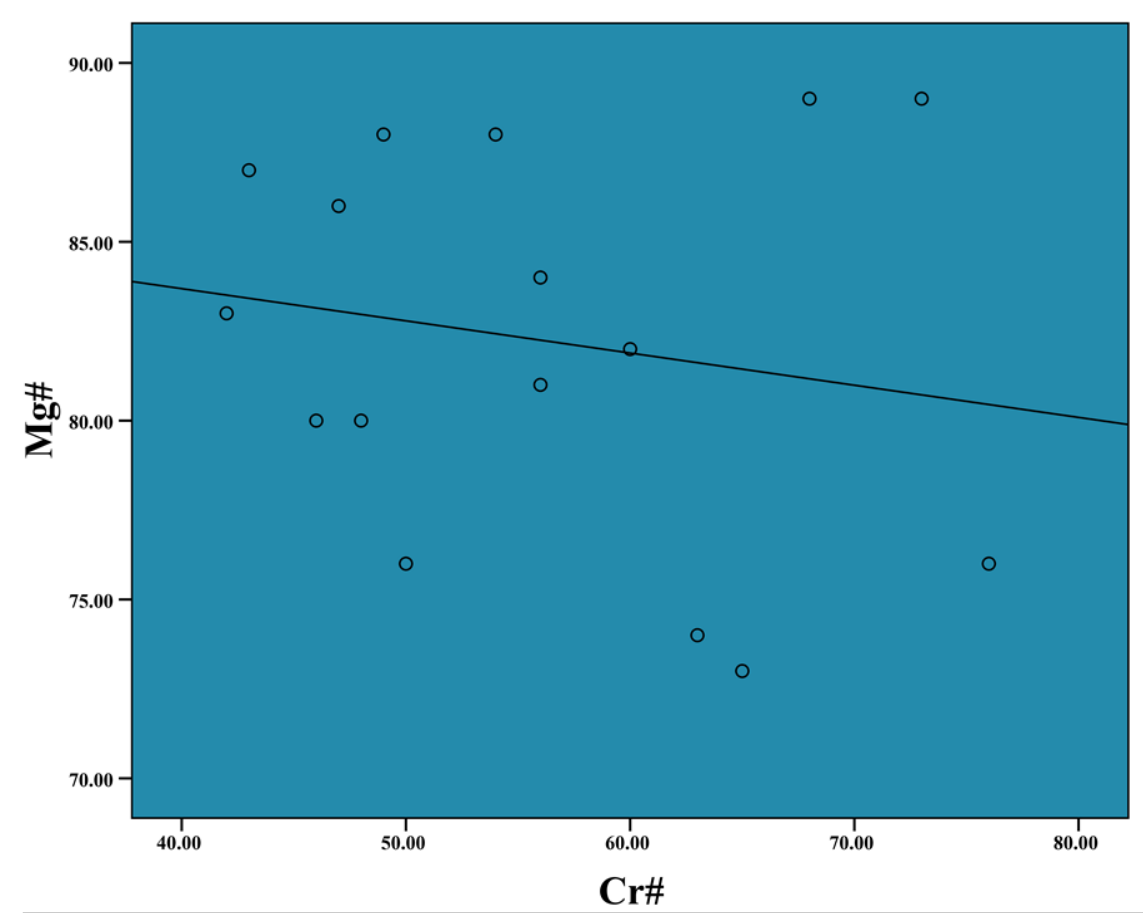

Figure 6. Negative correlation between $\mathrm{Cr} \#$ and $\mathrm{Mg} \#$ in chromitites of Dowlat AbadTang e Hana.

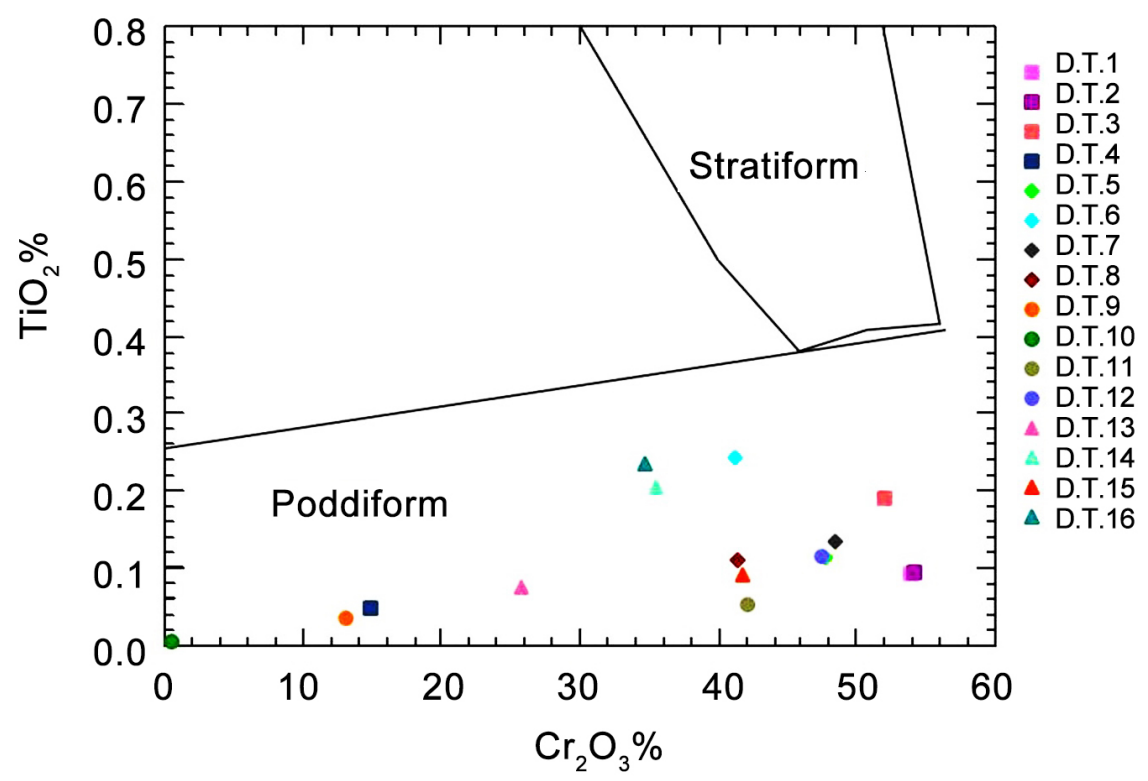

Figure 7. The status of Dowlat Abad-Tang e Hana area chromitites [57].

The low amount of $\mathrm{TiO}_{2}$ may be related to melting and subtraction processes of parent magma. By increasing the amount of melting in some parts of the primary rock, due to magma dilution, titanium oxide concentration decreases [58] [59]. Compared to High-Al chromites, High-Cr chromites (such as Dowlat Abad-Tang e Hana area chromites), are depleted from titanium more, which is regarded as a sign for more titanium with drawal during melting of upper mantle 
with higher degree [60] [61]. Taking the depletion of Dowlat Abad-Tang e Hana chromites from $\mathrm{TiO}_{2}$ into account, it is concluded that after melting the depleted mantle with higher degree above the subduction zone, the rising melt from the primitive mantle causes chromite mineralization. The effective role of $\mathrm{Mg}$-rich boninite magmatism resulted from partial melting with higher degree is another interesting point [55] [62] [63], since one of the features of bonitite magma is high amount of $\mathrm{MgO}$ (over 9\%) and low amount of $\mathrm{TiO}_{2}$ (less than 3\%) which is usually created at low pressure (less than $50 \mathrm{~km}$ ) and areas above subduction zone [64].

\section{Results and Discussion}

Based on previous work [65], the high amount of $\mathrm{Cr} \#$ and low amount of $\mathrm{Al}_{2} \mathrm{O}_{3}$ of the chromites of the area under study clarifies the lack of chromite formation of the area in expanding areas behind the arc and rift zone. In the other hand, the study area is situated on the northern margin of Zagros fold and thrust belt. From tectonics point of view, it contains orogenic belt of Arabian plate. Based on previous work on the salt and mud diapirism [66]-[81] and neotectonic regime in Iran [82]-[87], Zagros is the most active zone [88]-[115]. Then, Alborz [116]-[156] and Central Iran [157]-[174] have been situated in the next orders.

\section{Conclusion}

Peridotites of Dowlat Abad-Tang e Hana area (East of Ophiolite Complex of Neyriz) often consist of harzburgite. Serpentinization is widely seen in the rocks of the area. $\mathrm{Cr}_{2} \mathrm{O}_{3}$ content and chrome number in chromitites of Dowlat AbadTang e Hana area represent ophiolite chromitites rich in chromium. High amount of $\mathrm{MgO}$, on one hand, represents the chromitite crystallization of the magmas of the area under study with high degree of partial melting, which is related to deep peridotites and represents the alpine type of the chromites of Dowlat Abad-Tang e Hana area, on the other hand. In the chromitites of this area, a negative correlation between Cr\# and Mg\# was observed. This type of relation is the common feature of ophiolite type chromites. The average of $\mathrm{Cr} \#=56$ in chromites of Dowlat Abad-Tang e Hana area indicates that the parent magma of the chromite may be rooted from an area devoid of Al. The high amount of $\mathrm{Cr} \#$ and low amount of $\mathrm{Al}_{2} \mathrm{O}_{3}$ of the chromites of the area under study clarifies the lack of chromite formation of the area in expanding areas behind the arc and rift zone [65]. Depletion of Dowlat Abad-Tang e Hana chromites from $\mathrm{TiO}_{2}$ and $\mathrm{Al}_{2} \mathrm{O}_{3}$ shows that after melting the depleted mantle with higher degree above the subduction zone, the rising melt from the primitive mantle causes chromite mineralization. Furthermore, high average of $\mathrm{MgO}$ and $\mathrm{TiO}_{2}$ depletion of the chromites of Dowlat Abad-Tang e Hana area are regarded as the features of bonitite magma.

\section{References}

[1] Dare, S.A.S., Pearce, J.A., McDonad, I. and Styles, M.T. (2009) Tectonic Discrimi- 
nation of Peridotites Using $\mathrm{fO}_{2}$-Cr-no and Ga-Ti-Fe ${ }^{3}$ Systematics in Chrome-Spinel. Chemical Geology, 261, 199-216. https://doi.org/10.1016/j.chemgeo.2008.08.002

[2] Morishit, T., Maeda, J., Miyashita, S., Kumagai, H., Matsumoto, T. and Dick, H.J.B. (2007) Petrology of Local Concentration of Chromian Spinel in Dunit from the Slow Spreading Southwest Indian Ridge. European Journal of Mineralogy, 19, 871 882. https://doi.org/10.1127/0935-1221/2007/0019-1773

[3] Dilek, Y., Furnes, H. and Shallo, M. (2008) Geochemistry of the Jurassic Mirdita Ophiolite (Albania) and the MORB to SSZ Evolution of a Marginal Basin Oceanic Crust. Lithos, 100, 174-209. https://doi.org/10.1016/j.lithos.2007.06.026

[4] Tribuzio, R., Tiepolo, M., Vannucci, R. and Bottazzi, P. (1999) Trace Element Distribution within the Olivine-Bearing Gabbros from the Northern Apennine Ophiolites (Italy): Evidence for Post-Cumulus Crystallization in MOR-Type Gabbroic Rocks. Contributions to Mineralogy and Petrology, 134, 123-133. https://doi.org/10.1007/s004100050473

[5] Rampone, E. and Piccardo, G.B. (2000) The Ophiolite-Ocenic Lithosphere Analogue: New Insights from the Northern Apennines (Italy). In: Dilek, Y., Moores, E.M., Elthon, D. and Nicolas, A., Eds., Ophiolites and Oceanic Crust. New Insights from Field Studies and the Ocean Drilling Program, Geological Society of America Special Paper, Vol. 349, The Geological Society of America, Boulder, 21-34.

https://doi.org/10.1130/0-8137-2349-3.21

[6] Pearce, J.A., Alabaster, T., Shelton, A.W. and Searle. M.P. (1981) The Oman Ophiolite as a Cretaceous Arc-Basin Complex: Evidence and Implications. Philosophical Transactions of the Royal Society of London, 300, 299-317. https://doi.org/10.1098/rsta.1981.0066

[7] Pearce, J.A., Lippard, S.J. and Roberts, S. (1984) Characteristics and Tectonic Significance of Supra-Subduction Zone Ophiolites. Marginal Basin Geology Society of London Special Publication, 16, 77-89. https://doi.org/10.1144/GSL.SP.1984.016.01.06

[8] Hebert, R. and Laurent, R. (1989) The Mineralogical Study of a Cross-Section through the Plutonic Part of the Troodos Ophiolite: New Constraints for Genesis of Arc-Type Ophiolite. In: Malpas, J., et al., Eds., Ophiolites-Oceanic Crustal Analogues, Cyprus Geological Survey, Nicosia, 149-164.

[9] Arvin, M. (1990) Petrology and Geochemistry of Ophiolites and Associated Rocks from the Zagros Suture, Neyriz. Iran. In: Malpas, J., Moores, E.M., Panayiotou, A. and Xenophontos, C., Eds., Ophiolites, Oceanic Crustal Analogues, Geological Survey Department, Nicosia, 351-365.

[10] Rabinson, P.T. and Malpas, J. (1990) The Troodos Ophiolite of Cyprus: New Perspectives on Its Origin and Emplacement. In: Malpas, J., Moores, E.M., Panayiotou, A. and Xenophontos, C., Eds., Ophiolites, Oceanic Crustal Analogues, The Geological Survey Department, Nicosia, 13-26.

[11] Hassanipak, A.A. and Ghazi, A.M. (2000) Petrology, Geochemistry and Tectonic Setting of the Khoy Ophiolite, Northwest Iran: Implications for Tethyan Tectonics. Journal of Asian Earth Sciences, 18, 109-121. https://doi.org/10.1016/S1367-9120(99)00023-1

[12] Hebert, R., Huot, F., Wang, C. and Liu, Z. (2003) Yarlung Zangbo Ophiolites (Southern Tibet) Revisited: Geodynamic Implications from the Mineral Record. Geology Society of London Special Publication, 218, 165-190. https://doi.org/10.1144/GSL.SP.2003.218.01.10

[13] Malpas, J., Zhou, M.F., Robinson, P.T. and Reynolds, P.H. (2003) Geochemical and Geochronological Constraints on the Origin and Emplacement of the Yarlung 
Zangbo Ophiolites, Southern Tibet. Geological Society of London Special Publication, 218, 191-206. https://doi.org/10.1144/GSL.SP.2003.218.01.11

[14] Parlak, O., Hoeck, V., Kozlu, H. and Delaloye, M. (2006) Oceanic Crust Generation in an Island Arc Tectonic Setting, SE Anatolian Orogenic Belt (Turkey). Geological Magazine, 141, 583-603. https://doi.org/10.1017/S0016756804009458

[15] Shafaii Moghadam, H. and Stern, R.J. (2011) Geodynamic Evolution of Upper Cretaceous Zagros Ophiolites: Formation of Oceanic Lithosphere above a Nascent Subduction Zone. Geological Magazine, 148, 762-801. https://doi.org/10.1017/S0016756811000410

[16] Moores, E.M., Robinson, P.T., Malaps, J. and Xenophonotos, C. (1984) Model for the Origin of the Troodos Massif, Cyprus, and Other Mid-East Ophiolites. Geology, 12, 500-503. https://doi.org/10.1130/0091-7613(1984)12<500:MFTOOT >2.0.CO;2

[17] Dilek, Y. and Moores, E.M. (1987) Regional Tectonics of the Eastern Mediterranean Ophiolites. In: Malpas, J., Moores, E.M., Panayiotou, A. and Xenophontos, C., Eds., Ophiolites, Oceanic Crustal Analogues, Geological Survey Department, Nicosia, 295-309.

[18] Dilek, Y. and Delaloye, M. (1992) Structure of the Kizildag Ophiolite. A SlowSpread Cretaceous Ridge Segment North of the Arabian Promontory. Geology, 20, 19-22. https://doi.org/10.1130/0091-7613(1992)020<0019:SOTKOA >2.3.CO;2

[19] Nouri, R. and Arian, M. (2017) Multifractal Modeling of the Gold Mineralization in the Takab Area (NW Iran). Arabian Journal of Geosciences, 10,105-111. https://doi.org/10.1007/s12517-017-2923-2

[20] Allahyari, K., Saccani, E., Pourmoafi, M., Beccaluva, L. and Masoudi, F. (2010) Petrology of Mantle Peridotites and Intrusive Mafic Rocks from the Kermanshah Ophiolitic Complex (Zagros Belt, Iran): Implications for the Geodynamic Evolution of Neo-Tethyan Oceanic Branch between Arabia and Iran. An International Journal on Ophiolites and Modern Oceanic Lithosphere, 35, 71-90.

[21] ShafaiiMoghdam, H., Stern, R.J., Kimura, J.I., Hirahara, Y., Senda, R. and Miyazaki, T. (2012) Hf-Nd Isotopic Constrain on the Origins of Zagros Ophiolites. The Island Arc, 21, 202-214. https://doi.org/10.1111/j.1440-1738.2012.00815.x

[22] Ricou, L.E. (1976) Evolution Structural Des Zagrides. La région clef de Neyriz (Zagros iranien). Mémoires de la Société géologique de France, 55, 140 p.

[23] Ricou, L.E., Braud, J. and Brunn, J.H. (1977) Le Zagros. Livre à la mémoire de A.F de Lapparent, Soc. Géol. France, Paris, 33-52.

[24] Berberian, M. and King, G.C.P. (1981) Towards a Paleogeography and Tectonic Evolution of Iran. Canadian Journal of Earth Science, 18, 210-265. https://doi.org/10.1139/e81-019

[25] Stampfli, G.M. and Borel, G.D. (2002) A Plate Tectonic Model for the Paleozoic and Mesozoic Constrained by Dynamic Plate Boundaries and Restored Synthetic Oceanic Isochrones. Earth and Planetary Science Letters, 196, 17-33. https://doi.org/10.1016/S0012-821X(01)00588-X

[26] Rollinson, H. (2008) The Geochemistry of Mantle Chromite from the Northern Part of the Oman Ophiolite: Inferred Parental Melt Compositions. Journal of Contributions to Mineralogy and Petrology, 156, 273-288.

[27] Pichard, H.M., Neary, C.R., Fisher, P.C. and Hara, M.J. (2008) PGE-Rich Podiformchromites in the Al Ays Ophiolite Complex, Saudi Arabia-An Example of Critical Mantel Melting to Extract and Concentrate PGE. Economic Geology, 103, 1507-1529.

[28] Hatton, C.J. and Von Gruenewaldt, G. (1987) The Geological Setting and Petroge- 
nesis of the Bushveld Chromitite Layers. In: Stowe, C.W., Ed., Evolution of Chromium Ore Fields, Van Nostrand Reinhold Company, New York, 109-143.

[29] Schulte, R.F., Taylor, R.D., Piatak, N.M. and Seal, R.R. (2010) Stratiform Chromite Deposit Model. U.S. Geological Survey Open File Report 2010-1232, 7 p.

[30] Arai, S. (1992) Chemistry of Chromian Spinel in Volcanic Rocks as a Potential Guide to Magma Chemistry. Mineralogical Magazine, 56, 173-184.

[31] Barnes, S.J. and Roeder, P.L. (2001) The Rang of Spinel Compositions in Terrestrial Mafic and Ultramafic Rocks. Journal of Petrology, 42, 2279-2302. https://doi.org/10.1093/petrology/42.12.2279

[32] Arai, S. and Yurimoto, H. (1994) Podiformchromites of the Tari-Misska Ultramafic Complex, Southwestern Japan, as Mantle-Melt Interaction Products. Economic Geology, 89, 1279-1288.

[33] Zhou, M.F. and Robinson, P.T. (1994) High-Cr and High-Al Podiformchromites, Western China: Relationship to Partial Melting and Melt/Rock Reaction in the Upper Mantle. International Geology Review, 36, 678-686.

[34] Dilek, Y. and Flower, M.F.J. (2003) Arc-Trench Rollback and Forearc Accretion: 2. A Model Template for Ophiolites in Albania, Cyprus, and Oman. Geological Society, London, Special Publications, 218, 43-68. https://doi.org/10.1144/gsl.sp.2003.218.01.04

[35] Golestani, M. (2013) Petrology, Geochemistry and Tectonic Setting Intrusive Massive of Baftophiolitic-Melange, Southeast of Kerman, Iran. Journal of Tethys, 1, 164176.

[36] Sarkarinejad, K. (2005) Structures and Microstructures Related to Steady-State Mantle Flow in the Neyriz Ophiolite, Iran. Journal of Asian Earth Sciences, 25, 859881. https://doi.org/10.1016/j.jseaes.2004.08.007

[37] Stöcklin, J. (1974) Possible Ancient Continental Margin in Iran. In: Burke, C.A. and Drake, C.L., Eds., The Geology of Continental Margins, Springer, New York, 873887. https://doi.org/10.1007/978-3-662-01141-6_64

[38] Alavi, M. (1994) Tectonics of Zagros Orogenic Belt of Iran, New Data and Interpretation. Tectonophysics, 229, 211-238. https://doi.org/10.1016/0040-1951(94)90030-2

[39] Haynes, S.J. and Reynolds, P.H. (1980) Early Development of Tethys and Jurassic Ophiolite Displacement. Nature, 283, 561-563. https://doi.org/10.1038/283561a0

[40] Ricou, L.E. (1974) Letudegeologiqes de la region de Neyriz (Zagros Iraniaen) etlevolution structural deszagride. These universite, Paris, 300.

[41] Falcon, N.L. (1967) The Geology of the Northeast Margin of the Arabian Basement Shield. Advancement Science, 24, 31-42.

[42] Nabavi, M.H. (1976) History of Iran Geology, Geological Survey and Mineral Exploration Country. 109 p.

[43] Sabzehei, M. (1996) Geological Map of the Neyriz. Geological Quadrangle Map $1 \backslash 100000$, No. 6848, Geological Survey of Iran. (In Persian)

[44] Babaie, H.A., Babaie, A.A., Ghazi, M. and Arvin, M. (2006) Geochemical, ${ }^{40} \mathrm{Ar} /{ }^{39} \mathrm{Ar}$ Age, and Isotop Data for Crustal Rocks of the Neyriz Ophiolite, Iran. Canada Journal Earth Science, 43, 57-70. https://doi.org/10.1139/e05-111

[45] SheikhiKarizaki, H. (2006) Ophiolite Rocks KhajehJamali Area (Shiraz) and Its Chromite Deposits. Geological and Mineral Exploration Country, 164 p.

[46] Karimi, M., Hosseini, Z. and Noori, K. (2016) Geochemical Distribution of Major, Trace and Rare Elements in Chromite Ores of Neyriz Ophiolite. Iranian Journal of 
Crystallography and Mineralogy, No. 1, 45-56.

[47] Shahrestani, S. and Alinia, F. (2013) Platinum Group Elements Geochemistry and Composition of Podiform Chromites from Khaje Jamali Ophiolite Complex, Neyriz, Southern Iran. Journal of Tethys, 1, 96-112.

[48] Alizadeh, S. (2017) Non-Diapiric Salt Domes in the West Zanjan, Central Iran. Open Journal of Geology, 7, 132-146. https://doi.org/10.4236/ojg.2017.72009

[49] Proenza, J.A., Zaccarini, F., Lewis, J.F., Longo, F. and Garuti, G. (2007) Chromian Spinel Composition and the Platinum-Group Minerals of the PGE-Rich Loma Peguerachromites, Loma Caribe Peridotite, Dominican Republic. Canadian Mineralogist, 45, 631-648.

[50] Attarzadeh, P., Yazdi, M., Karimi, M. and Noori, K.K. (2016) Petrology and Geochemistry of Ophiolitic Host Rocks of Copper Mineralization in Dowlat AbadTang e Hana (Neyriz-Iran). Open Journal Geology, 6, 703-720.

[51] Davodi, Z., Rahgoshai, M. and Monsef, I. (2014) Geochemistry and Petrogenesis of Neyriz Ophiolite Complex (Southwest of Iran). Journal of Petrology, No. 19, 53-66.

[52] Leblanc, M. and Violette, J.F. (1983) Distribution of Aluminum-Rich and Chromium-Rich Chromite Podeform in Ophiolite Peridotites. Economic Geology, 78, 293-301. https://doi.org/10.2113/gsecongeo.78.2.293

[53] Moore, F. and Ghasemi, K. (1997) Chromite Geochemistry of Ophiolite méLange Texture and Solid Inclusions. The 1 st Meeting of the Geological Society of Iran, Iran 9-10 September 2007.

[54] Proenza, J.A., Gervilla, F., Melgarejo, J.C. and Bodinier, J.L. (1999) Al and Cr Rich Chromites from the Mayari-Baracoa Ophiolitic Belt (Eastern Cuba): Consequence of Interaction between Volatile-Rich Melts and Peridotites in Supra Subduction Mantle. Economic Geology, 94, 547-566.

[55] Dick, H.J.B. and Bullen, T. (1984) Chromian Spinel as a Petrogenetic Indicator in Abyssal and Alpine-Type Peridotites and Spatially Associated Lavas. Contributions to Mineralogy and Petrology, 86, 54-76.

[56] Zaccarini, F., Pushkarev, E. and Garuti, G. (2001) Platinum Group Element Mineralogy and Geochemistry of the Kluchevskoy Ophiolite Complex, Central Urals (Russia). Ore Geology Review, 33, 20-30. https://doi.org/10.1016/j.oregeorev.2006.05.007

[57] Ferrario, A. and Garuti, G. (1988) Platinum Group Mineral Inclusion in Chromites of Mafic-Ultramafic Complex (Ivrea-Zone, Italy). Mineral Petrol, 41, 125-143. https://doi.org/10.1007/BF01168491

[58] Maurel, C. and Maurel, P. (1982) Etude experimentale de la distribution de 1 aluminium entre bain silicate basique et spinellechromifere. Implications petrogenetiques: Teneuren chrome des spineless. Bulletin de Mineralogie, 105, 197-202.

[59] Kamenetsky, V.S., Crawford, A.J. and Meffer, S. (2001) Factors Controlling Chemistry of Magmatic Spinel: An Empirical Study of Associated Olivine, Cr-Spinel and Melt Inclusions from Primitive Rocks. Journal of Petrology, 42, 655-671.

[60] Jan, M.Q. and Windley, B.F. (1990) Chromium Spinel-Silicate Chemistry in Ultramafic Rocks of the Jijal Complex, Northwest Pakistan. Journal of Petrology, 31, 667 715.

[61] Bridges, J.C., Prichard, H.M. and Meireles, C.A. (1995) Podiform Chromite-Bearing Ultramafic Rocks from the Bragança Massif, Northern Portugal: Fragments of Island Arc Mantle? Geological Magazine, 132, 39-49. https://doi.org/10.1017/S0016756800011419

[62] Taylor, R.N., Nesbitt, R.W., Vidal, P., Harmon, R.S., Auvray, B. and Croudace, I.W. 
(1994) Mineralogy, Chemistry and Genesis of the Boninite Series Volcanic, Chichijima, Bonin Island, Japan. Journal of Petrology, 35, 577-617. https://doi.org/10.1093/petrology/35.3.577

[63] Uysal, I., Zaccarini, F., Sadilkar, M.B., Tarkin, M., Thalhammer, O.A.R. and Garuti, G. (2009) The Podiformchromites in the Dagkuplu and Kavak Mines, Eskisehir Ophiolite (NW-Turkey): Genetic Implications of Mineralogical and Geochemical Data. Geologica Acta, 7, 351-362.

[64] Mondal, S., Ripley, E.M., Li, C. and Frei, R. (2006) The Genesis of Archaean Chromite from the Nuasahi and Sukinda Massifs in the Singhbhum Craton, India. Precambrian Research, 148, 45-66. https://doi.org/10.1016/j.precamres.2006.04.001

[65] Hubbard, I., James, R.S., Easton, R.M. and Corfu, F. (1998) Origin of Metapyroxenites and High Al-Chromites from the Grenvile Front Tectonic Zone near Sudbury, Ontario. Geochemical Society of America, Washington DC.

[66] Arian, M. (2011) A Preface on Salt Diapirism of Iran. AsarNafis Press, Qum, 309 p.

[67] Arian, M. and Noroozpour, H. (2015) The Biggest Salt-Tongue Canopy of Central Iran. Open Journal of Geology, 5, 55-60. https://doi.org/10.4236/ojg.2015.52005

[68] Asadian, F., Pourkermani, M. and Arian, M. (2007) Tectonic Geomorphology of Salt Structures in the Garmsar-Lasjerd Area. Geographical Research, 39, 75-84.

[69] Pourkermani, M. and Arian, M. (1997) Salt Domes of Central Iran. Journal of Humanities, 3, 29-41.

[70] Arian, M. (2012) Salt Diapirism and Tectonics. 2nd Edition, AsarNafis Press, Qum, $319 \mathrm{p}$.

[71] Arian, M. and Noroozpour, H. (2015) Tectonic Geomorphology of Iran's Salt Structures. Open Journal of Geology, 5, 61-72. https://doi.org/10.4236/ojg.2015.52006

[72] Asadian, F. and Arian, M. (2009) Identification of Diapiric Provinces of Central Iran through Geological and Geographical Analysis. International Journal of Agriculture Environment \& Biotechnology, 2, 3443-3451.

[73] Arian, M. (2012) Clustering of Diapiric Provinces in the Central Iran Basin. Carbonates and Evaporites, 27, 9-18. https://doi.org/10.1007/s13146-011-0079-9

[74] Khodabakhshnezhad, A. and Arian, M. (2016) Salt Tectonics in the Southern Iran. International Journal of Geosciences, 7, 367-377. https://doi.org/10.4236/ijg.2016.73029

[75] Arian, M. (2010) Tectonics and Sedimentation. Farazamin Press, Tehran, 307 p.

[76] Arian, M. and Maleki, Z. (2010) Principals of Experimental Tectonics. AsarNafis Publication, Qum, $224 \mathrm{p}$.

[77] Pourkermani, M. and Arian, M. (1998) Tectonic Geomorphology of Salt Domes in West of Zanjan Province, Iran. Geographical Research, 47, 44-53.

[78] Arian, M. and Feizi, F. (2010) The Significance of Faulting on the Surficial Spreading of Evaporitic Deposits in the Varamin-Semnan Area. Journal of Earth and Resources, 3, 1-20.

[79] Razaghian, G. and Arian, M. (2015) The Emergent Salt Diapirs in the East Zagros, Iran. Open Journal of Geology, 5, 718-726. https://doi.org/10.4236/ojg.2015.510063

[80] Feizi, F., Arian, M. and Arian, A. (2015) Mud Diapirism on the Makran, Iran: Case Study on the Napag Mud Volcano. Open Journal of Geology, 5, 300-308. https://doi.org/10.4236/ojg.2015.55027

[81] Arian, M. and Sistanipour, A. (2015) Mud Diapirism on the Gorgan. North Iran Open Journal of Geology, 5, 442-450. https://doi.org/10.4236/ojg.2015.56041 
[82] Arian, M. and Khodabakhshnezhad, A. (2015) Sedimentary Environments Can Be Changed by Geotechnology (Case Study: A Morphotectonic Idea for Design of Extensive Artificial Bay on the Iranian Plateau). International Journal of Geosciences, 6, 487-496.

[83] Arian, M. (2011) Middle East Tectonics. AsarNafis Press, Qum, 236 p.

[84] Arian, M. (2010) Applied Seismotectonics. Farazamin Press, Tehran, 304 p.

[85] Arian, M. and Maleki, R. (2008) Neotectonics. Farazamin Research Center, Tehran, 150.

[86] Pourkermani, M. and Arian, M. (1998) Seismicity of Iran. Shahid Beheshti University Press, Tehran, 212.

[87] Pourkermani, M. and Arian, M. (1997) Seismotectonics. DezAb Consulting Engineers Company Press, Tehran, 270.

[88] Arian, M. and Aram, Z. (2014) Relative Tectonic Activity Classification in the Kermanshah Area, Western Iran. Solid Earth, 5, 1277-1291.

[89] Mashal, M., PourKermani, M., Charchi, A., Almasian, M. and Arian, M. (2013) Pattern of Structural Geology Underground in Eastern of North Dezfol Embayment. Advances in Environmental Biology, 7, 260-268.

[90] Pazhoohan, M., Arian, M., Ghorashi, M. and Khosrotehrani, K. (2014) A Study of Drainage Pattern Responses to Active Tectonics in Tadvan Region, SW Iran. Geodynamics, 1, 36-41.

[91] Rahimi, N. and Arian, M. (2014) Tectonic Geomorphplogy of Kangavar-Sosangerd Region, West Iran. Advances in Environmental Biology, 8, 119-124.

[92] Arian, M. and Hashemi, A. (2008) Seismotectonic Zoning in the Zagros. Journal of Sciences, 18, 63-76.

[93] Arian, M., Ahmadnia, A., Qorashi, M. and Pourkermani, M. (2002) Structural Analysis of Mengharak Transcurrent Fault System in Zagros, Iran. Special GEO 2002 Conference Issue Geoarabia, 7, 209-210.

[94] Arian, M., Qorashi, M., Pourkermani, M. and Ahmadnia, A. (2003) Fractal Analysis of Mengharak Transcurrent Fault System in Zagros, Iran. Proceedings of the 4 th International Conference on Seismology and Earthquake Engineering, Tehran, 12-14 May 2003, 23.

[95] Baharvand, S., Pourkermani, M., Ajalloian, R., Arian, M. and Nouryazdan, A.R. (2010) Seymareh Landslide and Its Role in Environmental and Geomorphologic Changes of the Pole-Dokhtar Area. Journal of the Earth, 4, 13-24.

[96] Abdideh, M., Qorashi, M., Rangzan, K. and Arian, M. (2011) Assessment of Relative Active Tectonics Using Morphometric Analysis, Case Study of Dez River (Southwestern, Iran). Geosciences, 20, 33-46.

[97] Arian, M., Qorashi, M., Pourkermani, M. and Ahmadnia, A. (2006) The Structural Significance Kareh Bas Transcurrent Fault System in the Zagros Fold and Thrust Belt. Geosciences, 15, 126-133.

[98] Arian, M. and Noroozpour, H. (2015) Seismic Activity and Fractal Geometry of Kareh Bas Fault System in Zagros, South of Iran. Open Journal of Geology, 5, 291299. https://doi.org/10.4236/ojg.2015.55026

[99] Ehsani, J. and Arian, M. (2015) Quantitative Analysis of Relative Tectonic Activity in the Jarahi-Hendijan Basin Area, Zagros Iran. Geosciences Journal, 19, 751-765. https://doi.org/10.1007/s12303-015-0016-3

[100] Omidali, M., Arian, M. and Sorbi, A. (2015) Neotectonics of Boroujerd Area, SW Iran by Index of Active Tectonics. Open Journal of Geology, 5, 309-324. 
https://doi.org/10.4236/ojg.2015.55028

[101] Chegini, A., Sorbi, A. and Arian, M. (2015) Active Tectonics of Hamedan Area, SW Iran by Index of Active Tectonics. International Journal of Geology, 4, 108-118.

[102] Maleki, Z., Arian, M., Solgi, A. and Ganjavian, M.A. (2014) The Elements of Fold Style Analysis in the Khaftar Anticline, Zagros, Iran. Open Journal of Geology, 4, 79-92. https://doi.org/10.4236/ojg.2014.43008

[103] Maleki, Z., Arian, M. and Solgi, A. (2014) Structural Style and Hydrocarbon Trap of Karbasi Anticline, in the Interior Fars Region, Zagros, Iran. Solid Earth Discussions, 6, 2143-2167. https://doi.org/10.5194/sed-6-2143-2014

[104] Ehsani, J., Arian, M. and Ghorashi, M. (2015) Geomorphic Signatures of Active Tectonics in the Jarahi-Hendijan Drainage Basin in the South West Iran. Geosciences, 24, 211-218.

[105] Khodabakhshnezhad, A., Pourkermani, M., Arian, M., Matkan, A.A. and Charchi, A. (2015) Active Tectonics of Great Karounriver Basin. Geosciences, 24, 13-28.

[106] Maleki, Z., Arian, M., Solgi, A. and Ganjavian, M.A. (2015) Elements of Fold Style Analysis in the Karbasi Anticline, Interior Fars Region, Zagros. Geosciences, 24, 293-302.

[107] Baratpour, F., Arian, M. and Solgi, A. (2015) Geometric Analysis of Tukak and Kamarun Anticlines on Izeh Zone, Zagros. Geosciences, 24, 191-200.

[108] GholamhoseinFard, N., Sorbi, A. and Arian, M. (2015) Active Tectonics of Kangavar Area, West Iran. Open Journal of Geology, 5, 422-441. https://doi.org/10.5194/sed-6-2143-2014

[109] Maleki, Z., Arian, M. and Solgi, A. (2015) Folding Pattern in the Fars Province, Zagros Folded Belt: Case Study on the Karbasi and Khaftar Anticlines, Interior Fars, Iran. Solid Earth Discussions, 7, 2347-2379. https://doi.org/10.5194/sed-7-2347-2015

[110] Aram, Z. and Arian, M. (2016) Active Tectonics of the Gharasu River Basin in Zagros, Iran, Investigated by Calculation of Geomorphic Indices and Group Decision Using Analytic Hierarchy Process (AHP) Software. Episodes, 39, 39-44. https://doi.org/10.18814/epiiugs/2016/v39i1/89235

[111] Abdolizadeh, S., Maleki, Z. and Arian, M. (2016) Earthquake Hazard Zonation and Seismotectonics of the Bandar Abbas Area, Zagros, Iran. Open Journal of Geology, 6, 210-224. https://doi.org/10.4236/ojg.2016.63019

[112] Hadizadeh, A., Arian, M. and Ganjouyan, M.A. (2011) Analysis Geometry Dashtak Detachment Zone in the Dashtak, Salamati and Sepidar Anticlines from Interior and Sub Coastal Fars Area. Journal of the Earth, 6, 33-44.

[113] Khodabakhshnezhad, A., Arian, M. and Pourkermani, M. (2008) The Elements of Fold Style Analysis in the Asmari Anticline (Zagros). Journal of Sciences, 18, 129138.

[114] Khodabakhshnezhad, A., Arian, M. and Pourkermani, M. (2015) Folding Mechanism in the Asmari Anticline, Zagros, Iran. Open Journal of Geology, 5, 197-208. https://doi.org/10.4236/ojg.2015.54018

[115] Arian, M., Pourkermani, M., Khodabakhshnezhad, A. and Noroozpour, H. (2011) Investigation of Oil Trap in the Asmari Anticline (Zagros, Iran). Indian Journal of Science and Technology, 4, 1696-1699.

[116] Alladin, Y., Talebian, M., Arian, M. and Ahmadi, M.M. (2015) Geotechnical Investigation and Seismic Zonation of Alluvial Deposits in Western Tehran. Geosciences, $24,333-342$. 
[117] Taherkhani, B., Nazari, H., Pourkermani, M. and Arian, M. (2015) Geometry and Recent Kinematics of the North Qazvin Fault: Morphotectonic Approach. Geosciences, 24, 29-38.

[118] Manuchehri, H., Arian, M., Ghorashi, M., Solgi, M. and Sorbi, A. (2015) Geomorphic Signatures of Active Tectonics in the Chalus Drainage Basin in the Alborz, Iran. Geosciences, 24, 273-280.

[119] Noroozpour, H., Arian, M. and Sorbi, A. (2015) Fault Movement Potentials in the Tehran-Semnan Region (North Iran). Open Journal of Geology, 5, 281-290. https://doi.org/10.4236/ojg.2015.55025

[120] Arian, M., Maleki, Z. and Noroozpour, H. (2011) Cenozoic Diastrophism and Deformational Events in the East Central Alborz. Journal of Basic and Applied Scientific Research, 1, 2394-2400.

[121] Feizi, F., Arian, A. and Rahmani, R. (2007) Seismotectonic Zoning in the Eastern Part of the Central Alborz. Journal of Sciences, 17, 151-164.

[122] Khavari, R., Arian, M. and Ghorashi, M. (2009) Neotectonics of the South Central Alborz Drainage Basin, in NW Tehran, N Iran. Journal of Applied Sciences, 9, 4115-4126. https://doi.org/10.3923/jas.2009.4115.4126

[123] Arian, M. and Bagha, N. (2012) Active Tectonics of Tehran Area, Iran. Journal of Basic and Applied Scientific Research, 2, 3805-3819.

[124] Bagha, N., Arian, M., Ghorashi, M., Pourkermani, M., El Hamdouni, R. and Solgi, A. (2014) Evaluation of Relative Tectonic Activity in the Tehran Basin, Central Alborz, Northern Iran. Geomorphology, 213, 66-87. https://doi.org/10.1016/j.geomorph.2013.12.041

[125] Arian, M. and Feizi, F. (2005) Application of Geomorphic Indices to the Assessment of Relative Tectonic Activity Levels in the Alborz-Central Iran Border Zone. Journal of Sciences, 15, 378-403.

[126] Arian, M., Bagha, N., Khavari, R. and Noroozpour, H. (2012) Seismic Sources and Neo-Tectonics of Tehran Area (North Iran). Indian Journal of Science and Technology, 5, 2379-2383.

[127] Moghimi, H., Arian, M. and Sorbi, A. (2015) Fault Movement Potential of Marzanabad Area, North Alborz, Iran. Open Journal of Geology, 5, 126-135.

[128] Arian, M. and Pourkermani, M. (2004) Tectonic Elements of South Flank in the East-Central Alborz Mountain. Journal of Sciences, 4, 359-368.

[129] Arian, M. and Qorashi, M. (2006) The Movement Potential Evaluation of the Major Quaternary Faults in Alborz-Central Iran Border Zone, from the East of Tehran to the East of Semnan. Journal of Geosciences, Geological Survey of Iran, 15, 184-188.

[130] Poroohan, N., Pourkermani, M. and Arian, M. (2013) An Assessment of Relationship in F-Parameter and Paleostress Fields in Heterogeneous Lithologies: Roudbar Area (Northwest of Iran). Australian Journal of Basic \& Applied Sciences, 7, 933942.

[131] Poroohan, N., Poukermani, M. and Arian, M. (2009) An Assessment on Correlations of Seismotectonic Parameters Preceding and Following Roudbar-Manjil Earthquake (Gilan, North of Iran). Australian Journal of Basic \& Applied Sciences, 3, 2643-2652.

[132] Farrokhnia, A.R., Pirasteh, S., Pourkermani, M. and Arian, M. (2011) Geo-Information Technology for Mass Wasting Hazard Zonation: Central-West Alborz-Iran. Disaster Advances, 4, 24-33.

[133] Khavari, R., Ghorashi, M. and Arian, M. (2009) Assessment of Relative Active Tectonics, South Central Alborz (North Iran). EGU General Assembly Conference Ab- 
stracts, 11, 1137.

[134] Sorbi, A., Arian, M. and Pourkermani, M. (2009) The Movement Potential Evaluation of the Major Quaternary Faults in Tehran Quadrangle. Journal of the Earth, 19, 176-182.

[135] Feizi, F. and Arian, M. (2006) The Classification of Thrust Fronts in the AlborzCentral Iran Border Zone from the East of Varamin to the East of Semnan. Journal of Sciences, 16, 75-87.

[136] Arian, M. and Pourkermani, M. (2004) Structural Significance of North Semnan and Attary Faults in Alborz-Central Iran Border Zone. Journal of Science, 14, 45514569.

[137] Arian, M. and Pourkermani, M. (2005) Cenozoic Diastrophism and Deformational Events in the Southern Flank of Central-East Alborz. Journal of Faculty Earth Sciences, 10, 43-51.

[138] Sadeghi, R., Saeedi, A., Arian, M., Ghorashi, M. and Solgi, A. (2015) Comparison of Strain Ellipsoid Shape in the South of Ardabil Range (NW) Based on the Results of the Magnetic Susceptibility Anisotropy and Paleostress Methods. Open Journal of Geology, 5, 611-622. https://doi.org/10.4236/ojg.2015.59054

[139] Arian, M., Pourkermani, M., Qorashi, M. and Ghasemi, M.R. (2003) North Semnan Fault System and Its Role on Basin Division. Proceedings of the 8th Symposium of Geological Society of Iran, Shahrood, 4-6 September 2003, 11-17.

[140] Pourkermani, M. and Arian, M. (2001) Structural Geomorphology of Northeastern Kurdistan. Journal of Humanities, 7, 37-48.

[141] Mardani, Z., Ghorashi, M. and Arian, M. (2011) Geomorphic Signatures of Active Tectonics in the Talaghanrud, Shahrud and Sefidrud Drainage Basins in Central Alborz, N Iran. Geosciences, 20, 159-166.

[142] Sorbi, A., Arian, M. and Pourkermani, M. (2011) The Application of Geomorphic Indices to the Assessment of Relative Tectonic Activity Levels in Tehran Quadrangle. Journal of the Earth, 6, 1-9.

[143] Khavari, R., Ghorashi, M., Arian, M. and Khosrotehrani, K. (2010) Geomorphic Signatures of Active Tectonics in the Karaj Drainage Basin in South Central Alborz, N Iran. Geosciences, 19, 67-74.

[144] Mousavi, E.J. and Arian, M. (2015) Tectonic Geomorphology of Atrak River, NE Iran. Open Journal of Geology, 5,106-114. https://doi.org/10.4236/ojg.2015.53010

[145] Nouri, R., Jafari, M.R., Arian, M., Feizi, F. and Afzal, P. (2013) Correlation between $\mathrm{Cu}$ Mineralization and Major Faults Using Multifractal Modelling in the Tarom Area (NW Iran). Geologica Carpathica, 64, 409-416. https://doi.org/10.2478/geoca-2013-0028

[146] Nouri, R., Jafari, M.R., Arian, M., Feizi, F. and Afzal, P. (2013) Prospection for Copper Mineralization with Contribution of Remote Sensing, Geochemical and Mineralographical Data in Abhar 1:100,000 Sheet, NW Iran. Archives of Mining Sciences, 58, 1071-1084. https://doi.org/10.2478/amsc-2013-0074

[147] Nouri, R., Afzal, P., Arian, M., Jafari, M. and Feizi, F. (2013) Reconnaissance of Copper and Gold Mineralization Using Analytical Hierarchy Process in the Rudbar 1:100,000 Map Sheet, Northwest Iran. Journal of Mining and Metallurgy, 49, 9-19.

[148] Farrokhnia, A.R., Pirasteh, S., Pradhan, B., Pourkermani, M. and Arian, M. (2011) A Recent Scenario of Mass Wasting and Its Impact on the Transportation in Alborz Mountains, Iran Using Geo-Information Technology. Arabian Journal of Geosciences, 4, 1337-1349. https://doi.org/10.1007/s12517-010-0238-7

[149] Arian, M. and Nouri, R. (2015) Lineament Tectonics and Mineralization in Tarom 
Area, North Iran. Open Journal of Geology, 5, 115-124.

[150] Feizi, F. and Arian, M. (2011) The Role of Structural Controllers in Geneses of Copper Deposits in 1:50000 Map of Saiin Qaleh. Journal of Sciences, 21, 1-10.

[151] Arian, M., Qorashi, M. and Ahmadnia, A. (2003) Analysis of Behbahan Shear Zone. Iranian Journal of Geology, 1, 1-4.

[152] Bahiraee, S., Arian, M., Qorashi, M. and Solgi, M. (2015) The Movement Potential Evaluation of the Mosha Fault (The West of Firoozkuh to the Shahrestanak). Geosciences, 24, 123-126.

[153] Bagha, N., Ghorashi, M., Arian, M., Pourkermani, M. and Solgi, A. (2015) Neotectonic Analysis of Mosha-North Tehran Fault Zone, Based on Morphotectonic Features, Central Alborz, Northern Iran. Geosciences, 24, 41-52.

[154] Mosavi, E. and Arian, M. (2015) Neotectonics of Kashaf Rud River, NE Iran by Modified Index of Active Tectonics (MIAT). International Journal of Geosciences, 6, 776-794.

[155] Nouri, R. and Arian, M. (2015) Structural Control on the Distribution of Hydrothermal Alteration Zones and Mineralization in Dastjerdeh Area Based on Remote Sensing Data, NW Iran. Bulletin of the Georgian National Academy of Sciences, 9, 79-86.

[156] Khosroshahizadeh, S., Pourkermani, M., Almasiyan, M., Arian, M. and Khakzad, A. (2015) Evaluation of Structural Patterns and Related Alteration and Mineralization Zones by Using ASAR-ASTER Imagery in Siyahrood Area (East Azarbaijan-NW Iran). Open Journal of Geology, 5, 589-610. https://doi.org/10.4236/ojg.2015.59053

[157] Sistanipour, A. and Arian, M. (2015) Geometric Analysis of Davaran Fault System, Central Iran. Open Journal of Geology, 5, 458-469. https://doi.org/10.4236/ojg.2015.56043

[158] Nazemi, M., Ghorashi, M., Ghassemi, M.R. and Arian, M. (2015) Morphotectonics Features of Alluvial Fans Associated with Active Tectonics (Shotori Mountains, East of Tabas-Central Iran). Geosciences, 24, 91-100.

[159] Alizadeh, H. and Arian, M. (2015) Rule of Structural Factors in Formation of Porphyry Copper Deposits in South Western Part of Kerman Area, Iran. Open Journal of Geology, 5, 489-498. https://doi.org/10.4236/ojg.2015.57045

[160] Mosavi, E.J. and Arian, M. (2015) Neotectonics of Tabas Area, Central Iran by Index of Active Tectonics (IAT). Open Journal of Geology, 5, 209-223.

[161] Daryani, N.J., Arian, M. and Omran, N.R. (2015) Tectonics and Mineralization of Copper in the Ardestan-Kahang Area, Central Iran by Remote Sensing. Open Journal of Geology, 5, 188-196.

[162] Arian, M. and Pourkermani, M. (2001) Rivers Morphology and Active Tectonic (Reviewing the Current Status of Ghezel Ozon River in the Province of Zanjan). Proceedings of the 5 th Conference of Geological Society of Iran, Tehran, 28-30 August 2001, 556.

[163] Arian, M., Toudeshki, V.H. and Noroozpour, H. (2011) Active Tectonics of QezelOzan River Basin, NW Iran. Journal of Applied Environmental and Biological Sciences, 1, 291-295.

[164] Alizadeh, H., Arian, M., Lotfi, M., Ghorashi, M. and Ghorbani, M. (2015) Determination of Porphyry Copper Deposit Locations Using Photo Lineament Factor in Northern Parts of the Dehaj-Sardoiyeh Belt. Geosciences, 24, 247-252.

[165] Toudeshki, V.H., Pourkermani, M., Arian, M. and Khosrotehrani, K.H. (2011) Influence of Structures on the GhezelOzan River. Geosciences, 21, 55-60. 
[166] Toudeshki, V.H. and Arian, M. (2011) Morphotectonic Analysis in the GhezelOzan River Basin, NW Iran. Journal of Geography and Geology, 3, 258-260. https://doi.org/10.5539/jgg.v3n1p258

[167] Arian, M. (2015) Seismotectonic-Geologic Hazards Zoning of Iran. Earth Sciences Research Journal, 19, 7-13. https://doi.org/10.15446/esrj.v19n1.40664

[168] Arian, M., Pourkermani, M., Sistanipour, A. and Noroozpour, H. (2011) Kinematic Significance of Fold- and Fault-Related Fracture Systems in the Rafsanjan's Northeast Highlands (Central Iran). Journal of Basic and Applied Scientific Research, 1, 3398-3406.

[169] Arian, M., Pourkermani, M., Sistanipour, A. and Noroozpour, H. (2011) Seismicity and Fault Segmentation of Bafq-Baghin Fault System (Central Iran). Journal of Applied Environmental and Biological Sciences, 1, 382-396.

[170] Arian, M. (2010) Earthquake-Fault Hazard Investigations in the Kerman Quadrangle. Journal of Sciences, 19, 176-182.

[171] Arian, M. and Sorbi, A. (2011) Remote Sensing Investigation of the Faults and Lineaments in the Karaj-Qazvin Region. Journal of the Earth, 5, 21-34.

[172] Arian, M., Alizadeh, H. and Noroozpour, H. (2011) Satellite Geometry of Faults and Fractures and Its Relationship with Porphyry Deposits in Northern Parts of Dahaj-Sardoiyeh Belt, South of Iran. Indian Journal of Science and Technology, 4, 1303-1306.

[173] Eshghi, Z., Arian, M. and Pourkermani, M. (2012) Structural Investigation on the Lak Mining Area (Bueen Zahra) Based on Remote Sensing, Used for Its Mineralization. Journal of the Earth, 6, 145-155.

[174] Mosavi, E.J., Arian, M., Ghorashi, M. and Nazemi, M. (2012) Measurements of Geomorphic Indices in Tabas Area. Journal of the Earth, 7, 213-225.

\section{Submit or recommend next manuscript to SCIRP and we will provide best} service for you:

Accepting pre-submission inquiries through Email, Facebook, LinkedIn, Twitter, etc. A wide selection of journals (inclusive of 9 subjects, more than 200 journals)

Providing 24-hour high-quality service

User-friendly online submission system

Fair and swift peer-review system

Efficient typesetting and proofreading procedure

Display of the result of downloads and visits, as well as the number of cited articles

Maximum dissemination of your research work

Submit your manuscript at: http://papersubmission.scirp.org/

Or contact ojg@scirp.org 